\title{
A WASTE OF SPACE? UNBUILT LAND IN THE BABYLONIAN CITIES OF THE FIRST MILLENNIUM BC ${ }^{1}$
}

\author{
$B y$ HEATHER D. BAKER
}

\begin{abstract}
Introduction
"One $\check{s} \bar{a} r$ is city, one $\check{s} \bar{a} r$ date-grove, one $\check{s} \bar{a} r$ is clay-pit, half a $\check{s} \bar{a} r$ the temple of Ištar: three $\check{s} \bar{a} r$ and a half (is) Uruk, (its) measurement". (Gilg. 1 22-3, XI 327-8; George 2003, 539, 725).
\end{abstract}

As this well-known passage from Gilgamesh reminds us, unbuilt land was integral to the Babylonian conception of the city. However, despite its importance, unbuilt land has received relatively little attention from scholars of ancient Near Eastern urbanism. This deficiency needs to be remedied, not least because attempting to assess the extent of unbuilt land is vital for any attempt to estimate the population of an ancient city, as we shall see. In addition to this, the presence of unbuilt land, not to mention its qualities - the size of the plots, their distribution, their modes of use, etc. - all shed valuable light on the physical form of the city as well as on the living conditions of its inhabitants. In this article therefore I shall discuss some of the key issues relating to unbuilt land in the cities of Babylonia in the first millennium $\mathrm{BC}$, highlighting the results of recent work in this area.

\section{The sources}

Excavations have taken place at a number of Babylonian settlements which were occupied during the first millennium BC. Key sites include Babylon, of course, but also the major cities of Borsippa, Sippar, Ur and Uruk. The technical standards by which excavations have been conducted vary considerably, and in the past archaeologists have often preferred to focus on the impressive monumental structures, such as the palaces and temples, rather to the neglect of other sectors, such as the residential districts. For these and other reasons, unbuilt land is under-represented in the archaeological record, a problem which I shall address in more detail below. Fortunately, however, the wealth of cuneiform economic documents from the first-millennium cities goes some way towards filling the gaps in our knowledge. Particularly important in this respect are the landsale tablets, which provide detailed information about individual urban properties which changed hands. In addition to these we have available a great many other tablets which shed light on urban topography and on the conditions of ownership and use of urban properties.

Tablets such as the one illustrated in Fig. 1 provide us with important information about the property which is the subject of the transaction, including details of the buyers and sellers and the price for which it was sold. They also allow us to draw up a schematic reconstruction of the immediate neighbourhood (e.g. Fig. 2), since they tell us what kinds of properties and/or topographical features adjoined the different sides of the property, giving the names of their owners where relevant. Information such as this, drawn from a large number of cuneiform tablets, provides a vital resource for studying the make-up of residential areas and especially for investigating unbuilt land in the city. Not only do we have contracts which are directly concerned with the transfer of plots of unbuilt land, but there are also a great many more which refer to such plots as neighbouring properties.

\section{Unbuilt land - a typology}

We may define unbuilt land in the most general - and rather self-evident - terms as a parcel of land lacking any built structures. However, such a broad definition is of limited use for analysing the use of space within the city: clearly, further sub-categories need to be delineated, each of which

\footnotetext{
${ }^{1}$ This article draws on a more detailed study of the urban landscape of Babylonia in the first millennium BC which is to be published shortly by the author (Baker forthcoming). The work has been carried out under the auspices of the START Project on "The Economic History

of Babylonia in the First Millennium BC" funded by the Fonds zur Förderung der Wissenschaftlichen Forschung (Austria) at the University of Vienna. This is an English version of an article published in the Dutch journal Phoenix $54 / 3(2008)$
}

Iraq LXXI (2009) 


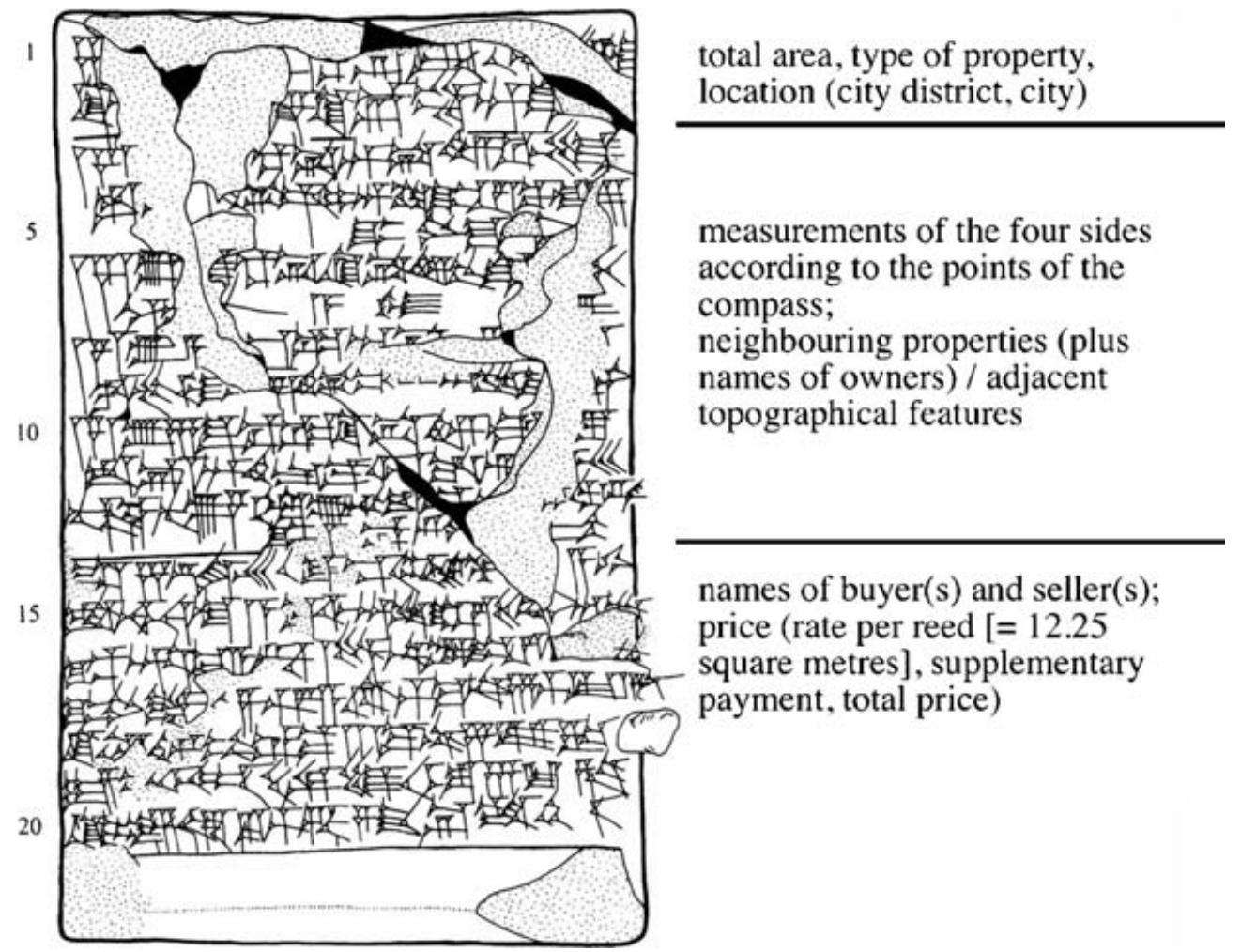

Fig. 1 House-sale tablet with a summary of its contents (obverse of BM 77513, published as Baker 2004, no. 80).

deserves detailed study in its own right. The following may be considered key categories:

- unbuilt urban plots in private ownership

- cultivable land within the city (gardens and orchards)

- public space, especially the street network

The study of each of these categories of land is vital for our understanding of how the city looked and how it functioned. In the following pages I shall discuss these different kinds of urban space and the key issues surrounding them.

\section{Unbuilt plots in private ownership}

With the first category we are dealing with plots located within areas of residential housing. The written record indicates that bare ground in this context was always owned by someone there is no record of any communal unbuilt plots, for example, nor indeed of any plots which were not attached to a particular individual or family. There is one exception to this rule: at Hellenistic Uruk the temple seems to have allocated plots of unbuilt land to members of its personnel who were then responsible for developing the land for residential purposes (Baker 2005, 30-7; Baker forthcoming). These plots were typically called "the property of (the god) Anu, the tenured property of so-and-so". Just occasionally we have references to unbuilt plots which were called simply "property of Anu", that is, they belonged to the temple but had apparently not yet been given out to any individual.

Aside from this one exception, unbuilt land in the residential areas was always in private ownership. This ties in well with the rather meagre archaeological evidence for unbuilt land in residential districts: such plots as can be identified seem to have been walled off, indicating that they belonged with an adjacent house (for example, Haus II in the Merkes quarter of Babylon; see Fig. 3). In general, plots of this kind can be difficult to detect in the archaeological record, not least because preparing the land for a subsequent building might obliterate all traces of them. 


\begin{tabular}{|c|c|}
\hline & $\begin{array}{l}\text { house of Rīhat-Anu, } \\
\text { son of Šamaš-iddin, } \\
\text { a reed-cutter(?) }\end{array}$ \\
\hline $\begin{array}{l}\text { house of Kidin-Anu, } \\
\text { son of Tanittu-Anu, } \\
\text { the buyer of that } \\
\text { unbuilt plot }\end{array}$ & $\begin{array}{l}\text { unbuilt plot } \\
\text { (kišubb û) }\end{array}$ \\
\hline & $\begin{array}{l}\text { orchard of date palms } \\
\text { belonging to Anu-ab-utēr, } \\
\text { son of Nikarchos, } \\
\text { descendant of Ahhūtu }\end{array}$ \\
\hline
\end{tabular}

Sellers: Anu-uballit and Anu-ahḩē-iddin, sons of

Anu-ab-utēr, grandsons of Nikarchos, descendants of

Ahhūtu

Buyer: Kidin-Anu, son of Tanittu-Anu, grandson of

Tattannu

Fig. 2 Schematic representation of the property described in the sale contract BRM 238 $(173 \mathrm{BC})$, located in the Ištar Gate district of Uruk. The buyer already owned the house on the west side; by purchasing this unbuilt plot he gained direct access to the Ištar Canal. One of the sellers owned an orchard on the south side of the property. The dimensions of the plot are not given in the tablet.

The most commonly used term for an unbuilt plot in the contemporary Babylonian tablets was kišubbû. Out of the corpus of over 1,100 cuneiform documents consulted in the author's study of Babylonian cities, more than 120 tablets mention urban plots designated kišubbĥu, thus offering a sizeable sample for the detailed investigation of this phenomenon. Upon examination of these sources it becomes clear that the word is used in different contexts. Moreover, it is worth differentiating between these contexts because in doing so we obtain further, important information about the make-up of residential districts.

In a small number of cases the cuneiform documents assign a specific function to plots which are called kišubbû. Usually in such instances we are dealing with unbuilt plots which actually functioned as blind alleys (Akkadian $m \bar{u} s \hat{u}$ ) serving individual houses or groups of houses. A couple of other cases involve a courtyard house that was incomplete; here the term kišubb $\hat{u}$ is used to describe the part of the house perceived as "missing":

"a built house with the door-jamb(s) fixed and the north(-facing) wing unbuilt" (BIN 1 127, 1-2 [Uruk, 589 BC])

"a north(-facing) wing and an east(-facing) wing, (both) built, and the remainder of the house which is to be torn down and rebuilt and (also consisting of ) unbuilt land" (GCCI 1 398, 5-6 [Uruk, 555 BC]) 


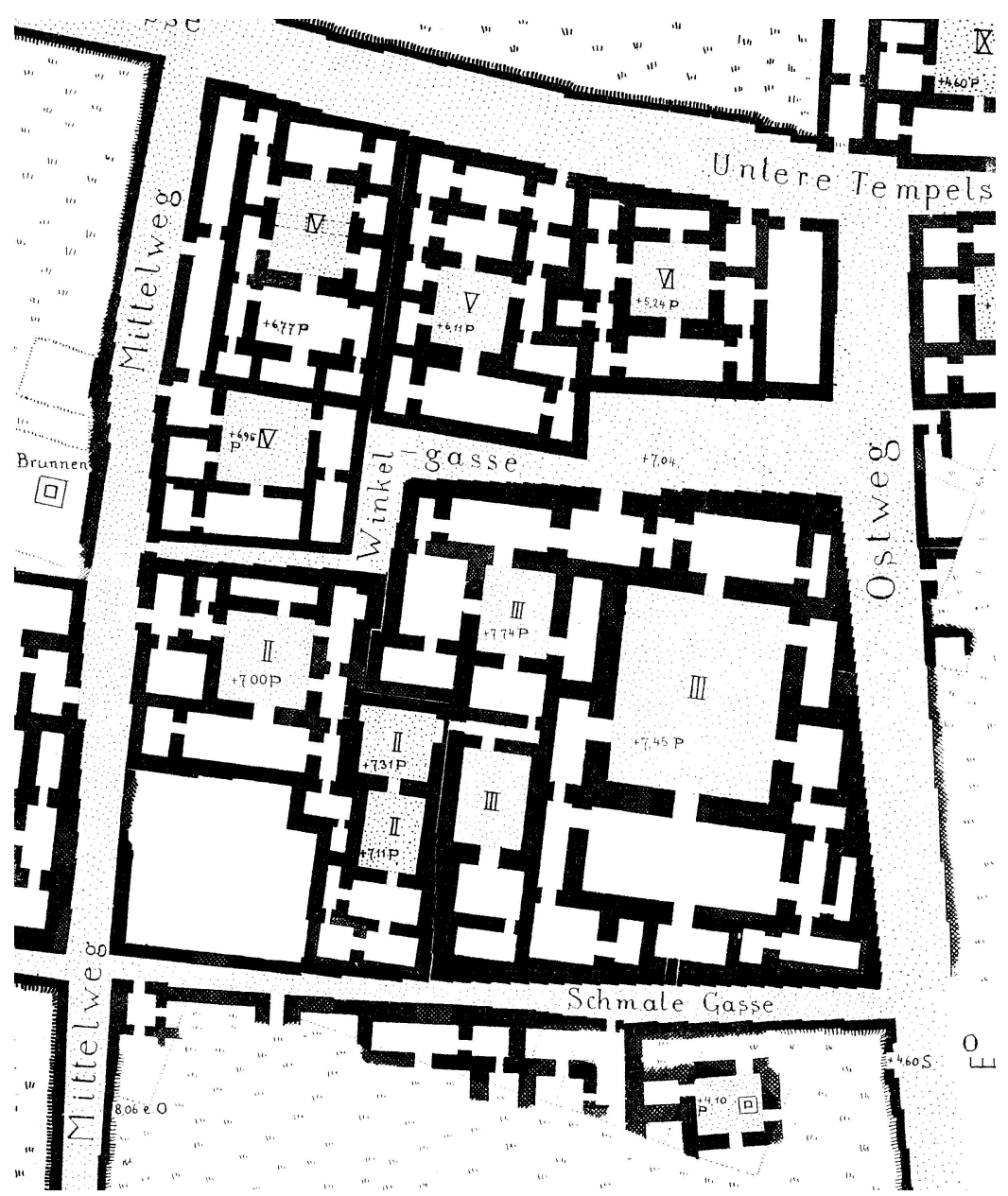

Fig. 3 A housing block excavated in the Merkes quarter of Babylon. Note the walled open area at the south-western corner of Haus II (after Reuther 1926, Taf. 17).

In the majority of cases, however, kišubbu plots are mentioned in the tablets without any further indication of their use. Among these kišubbu plots which figure as the subject of transactions it is useful to distinguish two sub-groups:

- kišubbû plots belonging to a house complex

- kišubbû plots sold independently of any house

An unbuilt plot sold or transferred as part of a house complex would have been situated on the house's exterior, as in the case of the Babylon house mentioned above (Haus II). These plots are not to be confused with the house's courtyard (in Akkadian, tarbasu), which was essentially an internal unroofed space that gave access to the rooms opening off it. Usually the courtyard was enclosed on all four sides by rooms, though sometimes only on three, or even two. Even where the courtyard lay adjacent to the house's exterior wall, it was still differentiated from an external $k i s ̌ u b b \hat{u}$ plot by virtue of the crucial role it played in articulating circulation patterns within the dwelling.

These external unbuilt plots belonging with house compounds are not uncommon in the documentation from Hellenistic Uruk, but they occur quite rarely in earlier times and in other cities. It is likely that this reflects a lower density of built-up occupation within the city of Uruk. We have no direct information as to the uses to which unbuilt plots belonging with houses were put. However, the written sources attest to the presence of ephemeral structures associated with houses, and at least some of these may have been situated on unbuilt plots forming part of the greater 
house complex. In the case of Haus II at Babylon, cited above, traces of flimsy structures were excavated at the northern end of the walled, unbuilt area to the south-west of the house (Reuther 1926, 92). The excavator suggested that the space to the south of these remains might have served as a garden, but this seems rather unlikely in view of the problem of water supply (see below).

In the second scenario outlined above we are dealing with plots which were sold on their own, without any accompanying structure. By definition, then, these plots were surrounded by neighbouring properties and/or streets. If we review the available data on the sizes of such plots, it becomes clear that many were too small comfortably to accommodate a courtyard house of the typical Neo-Babylonian type, which required $c a 90 \mathrm{~m}^{2}$ at least. In the light of this it seems reasonable to suggest that these smaller unbuilt plots were often being purchased specifically in order to extend adjacent properties. In fact, this hypothesis is backed up by the ownership data, which show that smaller, independent kišubbû plots were more frequently purchased by someone who already owned one of the adjacent properties. Thus we can detect a process of infilling, with the take-up of available unbuilt plots leading to a greater density of built-up space by the extension of existing houses.

At the other end of the scale, we have written evidence for a small number of very large unbuilt plots; these were presumably purchased in order to redevelop the land, and they could have accommodated a number of houses. One such case comes from Sippar during the reign of Nebuchadnezzar II - it is surely no coincidence that this was a time of significant economic revival and urban growth. The plot in question measured a staggering $5596.5 \mathrm{~m}^{2}$ (tablet BM 42340 , edited by Jursa 1999, 142-4). It was described as a kišubbû plot with ruined buildings on it.

\section{Unbuilt plots as an index of occupation density}

The frequency and distribution of unbuilt plots within the residential areas potentially serves as an index of occupation density. We have seen that such unbuilt land represented an opportunity to increase the density of building, either by extending existing dwellings or by erecting new ones, given a sufficiently large area. In the light of this it is clear that changes in the availability of these plots over time may reflect demographic processes. With the data available from first-millennium BC Babylonia it is possible to examine two key issues: (1) variability in occupation densities across one city at a particular period (Hellenistic Uruk); (2) demographic processes as reflected in changes in occupation densities over time. In the following paragraphs I shall outline some of the results recently obtained in studying these two issues.

\section{Variability in occupation densities within the city}

The documentary evidence for urban properties in Hellenistic Uruk is sufficient to allow us to address the question of variable occupation densities across the city. This is an important issue because attempts by archaeologists to estimate urban populations have been hamstrung by not knowing how far they can assume relatively small excavated areas of housing to be typical for the city as a whole. One approach is to take a multiplier such as the number of persons per hectare; using this method, one only needs to know the size of the settlement at the period in question (which is not necessarily a straightforward matter!). A more sophisticated procedure relies on using the number of inhabitants per house (plus an estimate of the number of houses per hectare) or, alternatively, the number of persons per square metre of roofed living space. Both of these latter approaches involve estimating the proportion of the settlement which was occupied by housing, therefore the extent and distribution of unbuilt space is a critical factor. These methods have been evaluated in detail by Postgate (1994), who examined three $50 \mathrm{~m}^{2}$ samples of residential area, two from Early Dynastic II-III Abu Salabikh and one from Old Babylonian Ur. On the basis of these samples he came up with figures of $10 \%$ of land occupied by public space (i.e. streets), and $90 \%$ taken up by residential space (houses). However, as he readily acknowledged, there was no way of determining whether or not these samples of residential areas were typical for the site as a whole.

For the first-millennium cities with which I am concerned, the archaeological evidence is insufficient for addressing these questions because no single site has been adequately sampled across its surface. However, the written data I have collected for Hellenistic Uruk suggests a 
significant degree of variability in occupation densities across the city. I shall now describe in brief the method used in arriving at this assessment. The full details of the analysis and the results obtained from it will be published shortly (Baker forthcoming).

If we take into account not only the properties which are the subject of transactions but also those which adjoined them, then our corpus of documented properties of known type is potentially quadrupled. To this end I used the available data for the five best-documented city districts from Hellenistic Uruk, namely the Adad Temple, Great/Royal Orchard, Ištar Gate, Lugalirra Temple and Šamaš Gate districts. All of the neighbouring properties mentioned in the relevant contracts were assigned to one of the following land-use categories (reflecting the Akkadian terminology and the native Babylonian practice in describing neighbouring features): house (bītu); unbuilt plot $(k i s ̌ u b b \hat{u})$; public street $(s \bar{u} q u)$; private alley $(m \bar{u} s \hat{u})$; other (much more rarely mentioned features such as canals, orchards); unknown (where the tablet is broken). I ignored the dimensions of the properties, since in many cases measurements of the individual sides were either not given in the tablet or were lost owing to damage. Thus the four sides of a quadrilateral plot were treated as being of equal length, even though this could not be verified and in fact is unlikely to have been the case, since properties were rarely square. However, it seemed plausible to suppose that the dimensions of individual sides would average out, given a sufficiently large sample. I was able to check the validity of this assumption by using the excavated residential area of Merkes in Babylon as a control: very similar results were obtained on aggregate when I took the excavated property boundaries and compared the results, treating them first as idealised boundaries (of equal length), and second as actual measured perimeters.

This analysis showed a significant degree of variation between the five city districts. Using the documented neighbouring properties as an index of relative density of occupation, it turned out that the Ištar Gate district was the most densely occupied: the boundaries of properties located in that district most frequently adjoined other houses and least frequently adjoined unbuilt plots. In four out of the five city districts, streets typically made up ca $20 \%$ or more of the property boundaries, suggesting that most properties had a public street running along one of their sides; a smaller number were served by an alley. So this analysis also provides us with important information for determining the size and composition of housing blocks.

It has to be stressed that the city districts studied here cannot be located with certainty on the plan of Uruk (though in some cases an approximate location can be proposed). Nevertheless, the very fact that it is possible to detect significant variation in occupation densities within the city at one period has important implications for studies of ancient urban demography.

\section{Changing occupation densities as evidence for demographic trends}

Looking at all the available data from the Babylonian cities, it is clear that the number of transactions involving independent kišubbû plots declined markedly from the seventh through to the fifth century $\mathrm{BC}$ (the period for which we have sufficient data to track chronological change). This suggests that plots available for building were becoming increasingly scarce. Over the same period there was a clear decline in average property size in general, taking into account all kinds of properties, as well as an increase in property prices. These trends, which were particularly marked in Babylon and Borsippa, suggest that there was increasing pressure on city space resulting from a rise in urban populations.

\section{Intramural gardens and orchards}

Gardens within the city were an important vehicle for displaying royal prestige. The location of the so-called 'Hanging Gardens' of Nebuchadnezzar II at Babylon remains a subject of dispute, but in tradition if not in fact the king emulated the example of his Neo-Assyrian forebears such as Sennacherib, who established a splendid park in his capital Nineveh. In the time of Alexander and his successors, gardens in Babylon are also documented, and in Uruk, too, a royal garden is known to have existed in the Hellenistic era.

However, most of the urban gardens and orchards to which our sources refer were in the hands of private individuals and, occasionally, temples. It comes as no great surprise that references to intramural cultivation in Babylon of the sixth and fifth centuries $\mathrm{BC}$ are more or less absent, 
because by that time the area within the circuit of the city walls was too densely occupied to afford space for it. However, between the double inner city wall and the outer defensive wall to the east, built by Nebuchadnezzar II as an extra line of defence, there were a great many orchards which were important in supplying the city. We should also bear in mind that the walled part of the city which lay on the western bank of the Euphrates is poorly known: it is largely unexplored archaeologically, and relatively few of the abundant cuneiform documents from Babylon refer to this side of the city. Still, for a detailed consideration of the question of intramural gardens and orchards, we have to look beyond Babylon.

The presence of gardens and orchards within a city presupposes, of course, an adequate water supply. The most efficient way to provide irrigation would be via an intramural watercourse other methods, such as the use of water-drawers, would be more labour-intensive than the maintenance of canals (leaving aside the labour involved in their initial construction). Generally, orchards and gardens would be restricted in their location to the low-lying margins of the site where they could be served by gravity-flow canals. However, in the case of larger, more loosely occupied sites, canals might pass between the different mounds which made up the settlement, as in the case of Old Babylonian Maškan-šāpir (Stone and Zimansky 2004).

It is fair to say that the question of the water supply of Mesopotamian urban sites, taking into account the pertinent hydrological and topographical conditions, has yet to receive the attention it deserves from archaeologists, and it is hoped that in future excavation and the study of high resolution satellite imagery etc. will contribute to illuminating this very important topic. For the present, we have a fair amount of relevant written evidence, both for intramural canals and for orchards and gardens. The physical perimeter of the city was also vital in this respect, since the moat formed a crucial element in the network of watercourses in and around the city, and textual sources show that often orchards were situated directly on the moat itself.

The best documentary evidence for intramural orchards and gardens comes from Uruk, a city for which we also have good physical evidence for watercourses within the city walls. ${ }^{2}$ Uruk was rather unusual at this period in having such a relatively small ratio of occupation area to walled city area: the space actually encompassed by its walls - which were, of course, an ancient legacy was huge. The area of the Hellenistic settlement has been estimated at $c a 300$ hectares, while for the Neo-Babylonian era the settled area was somewhat smaller. At the most, then, the first millennium settlement took up just over half of the total walled area of $c a 550$ hectares, leaving ample space for unbuilt land, not to mention orchards and gardens, especially around the lowerlying margins of the tell.

Among the first-millennium sources from Uruk I have been able to identify the names of over ten intramural watercourses (the last study of the Uruk topography, published by Falkenstein in 1941, named only one, but the available documentation has increased dramatically since that time). Orchards are attested, both in private ownership and forming part of the estate of various temples. In addition to these "formal" orchards we also have evidence for small stands of date palms belonging with houses: a couple of tablets involve house complexes situated on a canal bank within the city, each with a row of seven date palms lining the waterfront.

\section{Public space: the street network}

The written sources make it clear that the street network of the Babylonian city was made up of a three-tier hierarchy of major public streets, minor public streets, and blind alleys. This is reflected in the Akkadian terminology; the following expressions are typically used:

- sūqu rapšu mùtaq ilāni u šarri - "broad street, way of the gods and the king"

- sūqu rapš́ mūtaq niš̃ — "narrow street, way of the people"

- $m \bar{u} s \hat{u}(l \bar{a} \bar{a} s \hat{u})$ - "(blind) alley (literally: exit)"

The major public streets often served as ceremonial routes (as is suggested by the popular designation "way of the gods and the king"). As well as this everyday, generic term, these

\footnotetext{
${ }^{2}$ See, for example, the reconstruction of the canal system in and around the city by Kose (1998, 14 Abb. 4), which is based
} on aerial photographs taken in 1935. 
important streets could also have "official" names reflecting their ceremonial character. We know this from the literary/topographical tablet series called Tintir = Babylon, which describes in some detail the topography of the city of Babylon in the late second millennium BC (George 1992, 1-72). Many of the features mentioned in Tintir were still present in the first millennium, not least because there was a strong inclination towards conservatism in the siting of cultic buildings and other features of religious significance. One historical source indicates that it was considered a taboo to divert the course of a ceremonial street.

Streets have, of course, been found in excavations. The best sample of a sector of street network is that of the Merkes area of Babylon. However, it is clear that blind alleys in general are underrepresented in the excavations on first-millennium sites, because the examples recovered are far fewer in number than the textual sources would lead us to expect. In Merkes itself the excavators traced the street network over several blocks beyond the actual excavation area by digging along the facades of the houses, but they seem not to have followed the more narrow openings between houses, at least some of which probably represented alleys (rather than simply the narrow gaps between adjacent houses which are sometimes found in this area).

Where deep soundings could be made in Merkes, they revealed the great antiquity of the street network, going back as far as the Old Babylonian period. In general, public streets defined the outer perimeter of housing blocks, but within those blocks property boundaries were much more fluid. The alleys which led into the heart of the residential blocks were owned privately by those whose houses they served, and they could be remodelled and even relocated according to the changing needs of those owners.

It is worth considering briefly the nature of public space in the Babylonian city. The temples were not places of public worship but, on the contrary, access to them was restricted, increasingly so as one approached the sacred chambers where the gods resided. The major public streets, being the conduit for the processions of the gods (in the form of the divine statues) and the king, played a major role in — quite literally — bringing religion to the people and in reinforcing cultural values and royal ideology. This cultic appropriation of public space - if we might call it that is reflected also in the presence around the city streets of a great many cultic daises, shrines and stations. For example, the literary/topographic tablet series Tintir, mentioned above, summarises the cultic structures located in Babylon:

43 cult-centres of the great gods in Babylon

55 daises of Marduk

300 daises of the Igigi

600 daises of the Anunnaki

180 shrines of Ištar

180 stations of Lugalirra and Meslamtaea

Tintir tablet V 11. 82-8 (George 1992, 68-9)

A couple of features have been excavated in the Merkes area of Babylon which might be identified as cultic structures of the kind listed in this passage of Tintir (see Fig. 4).

On a more mundane level, the streets provided the setting for commercial activities. Buying and selling was conducted there, and the written evidence from Hellenistic Uruk reveals the existence of rows of shops located along some of the major public streets (Baker forthcoming). The areas around the city gates were no doubt also important for trade, just like their counterparts in the traditional Islamic cities later on. But there is no evidence at this time for public squares forming a part of the street network, nor indeed for any kind of formal civic space comparable to the Greek agora or the Roman forum, at least until the Hellenistic era when the Greek theatre at Babylon served also as a place of assembly (van der Spek 2001).

\section{Conclusions}

By using both the archaeological and the written sources for the Babylonian cities it is possible to make significant progress in understanding the characteristics of unbuilt urban land, a topic which has until now proved rather elusive. Within the residential areas, unbuilt plots were privately owned or were (in the case of Hellenistic Uruk) occasionally owned by the temple but destined 


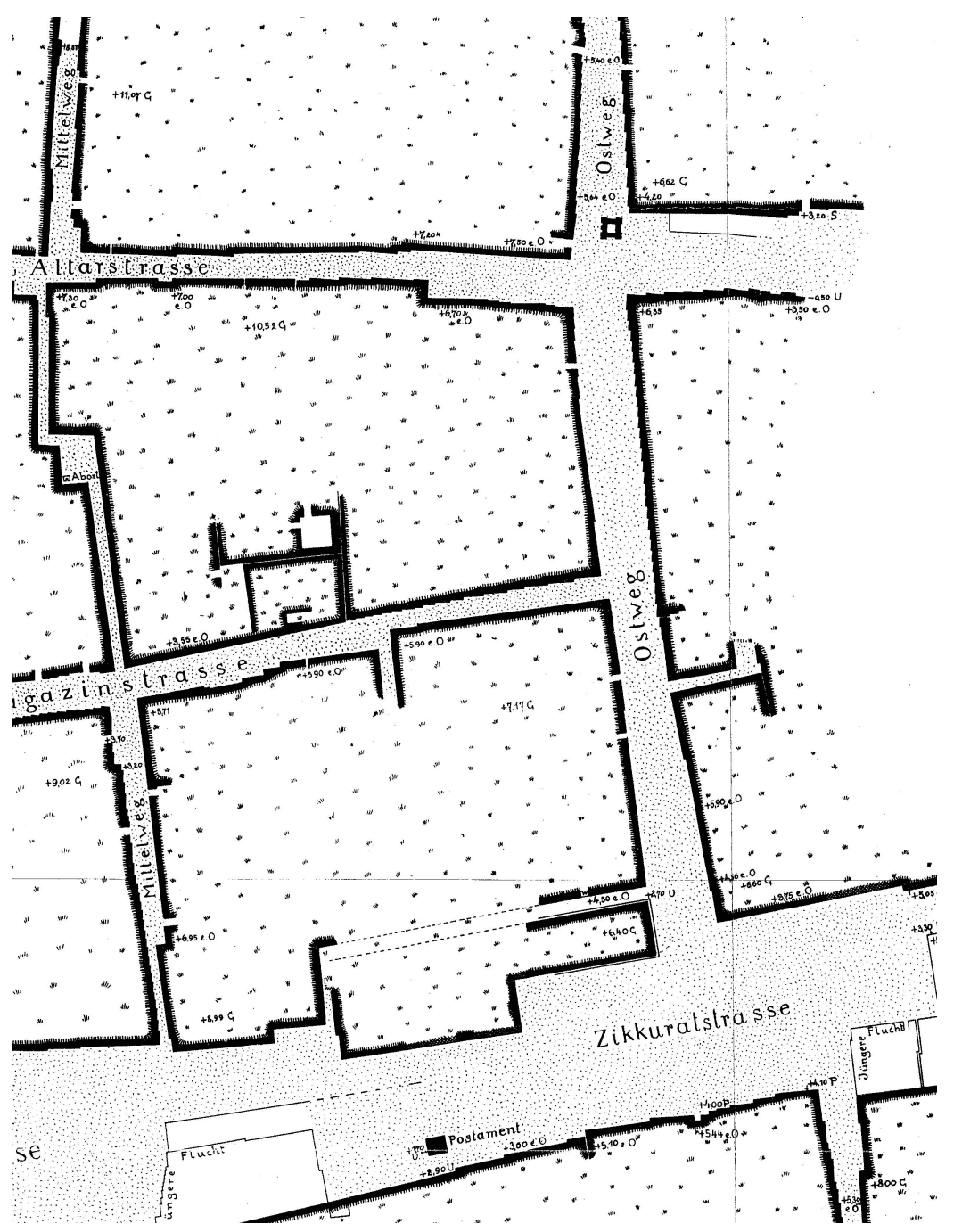

Fig. 4 Part of the street network in Merkes, Babylon (after Reuther 1926, Taf. 18). Note the "Postament" in Zikkuratstrasse and the "altar" at the junction of Altarstrasse and Ostweg.

for private hands. There is no evidence for land in these areas serving as a dumping ground or wasteland; it is possible that social convention and/or pressure on space in the built-up areas militated against this. At any rate, ownership was a key factor, with urban plots being carefully surveyed and, where necessary, delimited by walls: such zealous delineation of private property would surely have inhibited the casual use of bare ground by outsiders. On the other hand, it seems most unlikely that the city was entirely devoid of wasteland, and one might imagine marginal areas, especially around the city's perimeter, to have played host to some of the more insalubrious activities known to mankind. Certain open-air facilities must have been accessible to the community, notably stretches of canal or river banks used for drawing water and washing clothes; at Uruk we have documentary evidence for a "Great Well", which presumably served the local residents. But the opportunities for public gatherings in a more formal context were largely restricted to the ceremonial processions on occasions dictated by the cultic calendar, when the inhabitants would have thronged the major public streets to witness such spectacles. I hope that this article has shown how the study of unbuilt land in all its variety contributes to forging a more detailed picture of how the Babylonian city was formed, shedding light on the living conditions of the inhabitants as well as on the question of urban demography, and raising compelling issues for further research. 
Abbreviations

BIN 1 Keiser, C. E. 1917, Letters and Contracts from Erech Written in the Neo-Babylonian Period. Babylonian Inscriptions in the Collection of James B. Nies 1. New Haven.

GCCI 1 Dougherty, R. P. 1923, Goucher College Cuneiform Inscriptions. Vol. I: Archives from Erech. Time of Nebuchadrezzar and Nabonidus. New Haven.

References

Baker, H. D.

2004 The Archive of the Nappāhu Family. AfO Beiheft 30. Vienna.

2005 "The property portfolio of a family of builders from Hellenistic Uruk," in H. D. Baker and M. Jursa (eds.), Approaching the Babylonian Economy. Proceedings of the START Project Symposium Held in Vienna, 1-3 July 2004. AOAT 330. Münster: 7-43.

Forthcoming. The Urban Landscape in First Millennium BC Babylonia.

Falkenstein, A.

1941 Topographie von Uruk I: Uruk zur Seleukidenzeit. Ausgrabungen der Deutschen ForschungsgemeinGeorge, A. R. schaft in Uruk-Warka 3. Leipzig.

1992 Babylonian Topographical Texts. Orientalia Lovaniensia Analecta 40. Leuven.

2003 The Babylonian Gilgamesh Epic. Introduction, Critical Edition and Cuneiform Texts. 2 vols. Oxford. Jursa, M.

1999 Das Archive des Bēl-rēmanni. PIHANS 86. Istanbul.

Kose, A.

1998 Uruk, Architektur IV. Von der Seleukiden- bis zur Sasanidenzeit. Ausgrabungen in Uruk-Warka, Postgate, J. N. Endberichte 17. Mainz am Rhein.

1994 "How Many Sumerians per Hectare? - Probing the Anatomy of an Early City," Cambridge Reuther, O. Archaeological Journal 4/1, 47-65.

1926 Die Innenstadt von Babylon (Merkes). 2 vols. Wissenschaftliche Veröffentlichungen der Deutschen van der Spek, R. J. Orient-Gesellschaft 47. Leipzig.

2001 "The Theatre of Babylon in Cuneiform," in W. H. van Soldt (ed.), Veenhof Anniversary Volume. Studies Presented to Klaas R. Veenhof on the Occasion of His Sixty-Fifth Birthday. Istanbul: 445-56.

Stone, E. C. and P. Zimansky

2004 The Anatomy of a Mesopotamian City: Survey and Soundings at Mashkan Shapir. Winona Lake, Indiana.

\section{Abstract}

This article uses both textual and archaeological evidence to examine the role of unbuilt land in the Babylonian city. Detailed study of such land is vital not only for understanding urban living conditions but also for any attempt to estimate urban population based on density of occupation of residential areas. By classifying and investigating unbuilt land according to its physical properties, modes of use and conditions of ownership, it is possible to reassess its role in the lives of the city-dwellers.

Heather D. Baker

Institut für Orientalistik

University of Vienna

Austria 